\title{
METAMORPHIC EVOLUTION OF THE PRECAMBRIAN BASEMENT OF ALBERTA
}

\author{
RONALD A. BURWASH§ ${ }^{\S}$ AND JIRI KRUPIČKA \\ Department of Earth and Atmospheric Sciences, University of Alberta, Edmonton, Alberta T6G 2E3, Canada
}

JAN R. WIJBRANS

Institute of Earth Sciences, Department of Petrology and Isotope Geology, Vrije Universiteit, De Boelelaan 1085, 1081 HV Amsterdam, The Netherlands

\begin{abstract}
The metamorphic facies of the subsurface Precambrian of Alberta are charted for the first time as a contribution to the new tectonometamorphic map of the Canadian Shield. Inferences about facies are based primarily on petrographically determined mineral assemblages. A few P-T determinations from results of electron-microprobe analyses are available. The chronology of metamorphic events is based primarily on extensive and previously reported $\mathrm{U}-\mathrm{Pb}, \mathrm{Rb}-\mathrm{Sr}, \mathrm{K}-\mathrm{Ar},{ }^{40} \mathrm{Ar}-{ }^{39} \mathrm{Ar}$ and $\mathrm{Sm}-\mathrm{Nd}$ geochronology. New U-Pb, ${ }^{40} \mathrm{Ar}-{ }^{39} \mathrm{Ar}$ and $\mathrm{Sm}-\mathrm{Nd}$ dates are reported for critical localities. All of Alberta was affected by a protracted series of early Proterozoic events. Late Archean (2700-2800 Ma) sialic crust in the southern half of the province was thermally overprinted at about $1800 \mathrm{Ma}$. In northern Alberta, older crust was dynamically, thermally and metasomatically reworked by a series of high-temperature events between 1750 and $1950 \mathrm{Ma}$.
\end{abstract}

Keywords: basement, metamorphic evolution, Canadian Shield, Alberta.

\section{SOMMAIRE}

Les faciès métamorphiques du socle précambrien formant le soubassement de l'Alberta sont ici évalués et résumés pour la première fois comme contribution à la nouvelle carte tectonométamorphique du Bouclier Canadien. Nos interprétations à propos des faciès reposent surtout sur les assemblages de minéraux déterminés en lame mince. Quelques déterminations de pression et de température sont disponibles à partir de résultats d'analyses à la microsonde électronique. La chronologie des événements métamorphiques est fondée surtout sur une volumineuse banque de données déjà publiée, comprenant des âges $\mathrm{U}-\mathrm{Pb}, \mathrm{Rb}-\mathrm{Sr}$, $\mathrm{K}-\mathrm{Ar},{ }^{40} \mathrm{Ar}-{ }^{39} \mathrm{Ar}$ et $\mathrm{Sm}-\mathrm{Nd}$. De nouvelles déterminations d'âges U-Pb, ${ }^{40} \mathrm{Ar}-{ }^{39} \mathrm{Ar}$ et $\mathrm{Sm}-\mathrm{Nd}$ ont été effectuées pour certains endroits importants. L'Alberta en entier a subi les effets d'une longue série d'événements protérozoïques. La croûte sialique tardiarchéenne (2700-2800 Ma) dans la moitié sud de la province a subi un réchauffement à environ 1800 Ma. Plus au nord, la croûte plus ancienne a été dynamiquement, thermiquement et métasomatiquement remaniée au cours d'une série de recristallisations à température élevée entre 1750 et 1950 Ma

(Traduit par la Rédaction)

Mots-clés: soubassement, évolution métamorphique, Bouclier Canadien, Alberta.

\section{INTRODUCTION}

The determination of metamorphic grade of the basement beneath the Western Canada Sedimentary Basin is highly dependent on core samples from deep drilling. Collection of such samples for petrographic study was started at the University of Alberta in 1940 by the late R.L. Rutherford. Accelerated deep drilling following the discovery of oil at Leduc provided material for thesis projects by Burwash $(1951,1957)$ and Peterman (1962).
The Basement Rock Project (BRP), sponsored by the AAPG, resulted in additional sampling and new data. The accumulated western Canadian BRP collection was studied by J. Krupicka in 1968-1969 and provided much of the mineral-assemblage data for the current map. The results of a number of studies carried out at the University of Alberta are summarized in the Decade of North American Geology (Burwash et al. 1993) and in the Geologic Atlas of the Western Canada Sedimentary Basin (Burwash et al. 1994). Maps in these two publi-

§E-mail address: ronald.burwash@ualberta.ca 
cations show lithologies of samples in the BRP collection and are not reproduced here. Results of whole-rock chemical analyses and petrographic data for the BRP suite are filed with the Lithoprobe Alberta Basement Transects database.

In drafting a new tectonometamorphic map of the Alberta basement, which is the main theme of this paper, emphasis has been placed on two kinds of data: metamorphic facies as determined by petrographic study by Burwash \& Krupicka, and the structural fabric of the basement reflected in aeromagnetic maps of Alberta. Supporting data from core samples come from many sources: the U-Pb geological framework was established by Ross et al. (1991), and the Sm-Nd data were added by Frost \& Burwash (1986) and Villeneuve et al. (1993). Plint \& Ross (1993) and Plint \& McDonough (1995) reported on the ${ }^{40} \mathrm{Ar}-{ }^{39} \mathrm{Ar}$ geochronology. New argon data are presented in this paper.

During the last five years, in the context of Lithoprobe Alberta Basement Transect, seismic profiles have been recorded across a number of the domain boundaries drawn by Ross et al. (1991). Oxygen isotopic analyses of some 200 basement core samples were undertaken at the University of Alberta. This led to the discovery by Muehlenbachs et al. (1993) of the Kimiwan Isotopic Anomaly (KIA), a feature previously unknown in northwestern Alberta. Burwash \& Muehlenbachs (1997) used Pearce trace-element discrimination diagrams to infer the tectonic setting of basement granites in the eastern half of Alberta. As many petrographically, isotopically, and geophysically defined boundaries as possible are used in preparing this latest tectonometamorphic map.

\section{Metamorphic Facies}

Determinations of the metamorphic facies reported in this paper are based on petrographically established assemblages. P-T determinations based on results of electron-microprobe analyses are available for many of the rock units of the exposed Shield in northeastern Alberta. Very high temperatures are indicated in the Taltson Magmatic Zone (Chacko 1997, Berman \& Bostock 1997). Similar studies in the subsurface have been initiated, and preliminary results are presented in the section dealing with the Red Earth granulite domain.

A statistical summary of metamorphic facies of core samples from the entire Western Canada Sedimentary Basin and from Alberta is given in Table 1. Relative to mapped rock units on the exposed part of the Shield west of Hudson Bay, unmetamorphosed and subgreenschistfacies rocks are meager in our suite. One reason for this scarcity is probably the reluctance of well-site geologists to identify subgreenschist-facies rocks as Precambrian basement. The relative scarcity of greenschistfacies samples suggests a second reason: almost all of the supracrustal rock units have been eroded from the Alberta basement.
The spatial distribution of data points for the metamorphic map is very uneven (Fig. 1). The high concentration of core samples in north-central Alberta, especially from map area NTS 84 B, Peerless Lake, introduces some bias in the statistics. Granulite and gneiss, penetrated in the closely spaced wells of the Peerless Lake area, are over-represented in the Alberta averages. Many NTS 84 B granulites are not plotted on Figure 1 to avoid overlapping symbols.

The distinction between granite and gneiss in core samples, without supporting observations at the outcrop, becomes subjective in part. "Granite" is used in a very broad sense and includes rocks ranging in composition from granite as defined by Streckeisen (1997) to quartz diorite, with a hypidiomorphic granular texture; such rocks are not foliated or are only weakly foliated. Many basement rocks from northern Alberta show petrographic evidence of strong deformation and recrystallization (Burwash \& Krupička 1969, 1970). Most of these are classified as gneiss, even where the protolith may have been granite. Most cores classified as "gneiss" probably reflect upper-amphibolite-facies metamorphic conditions. However, only those that contain diagnostic mineral assemblages indicative of specific facies are plotted on Figure 1. The distinction between diorite and amphibolite or charnockite and granulite is also partly subjective without outcrop data. The following criteria are adopted for naming drill-core samples: strongly foliated rocks are metamorphic, and unfoliated or weakly foliated rocks are igneous.

\section{TeCTONOMETAMorphic ELEMENTS}

There are too few core samples of basement available from Alberta to draw a map of metamorphic domains, even after due diligence in assigning facies to all samples with indicator assemblages of metamorphic minerals. Ross et al. (1991) used aeromagnetic anomaly maps to draw boundaries between domains with distinct $\mathrm{U}-\mathrm{Pb}$ ages. We have modified their approach by com-

TABLE 1. METAMORPHIC FACIES OF BASEMENT CORE SAMPLES, WESTERN CANADA SEDIMENTARY BASIN AND ALBERTA

\begin{tabular}{|c|c|c|c|c|}
\hline & \multicolumn{2}{|c|}{ WCSB } & \multicolumn{2}{|c|}{ Alberta } \\
\hline & Number & $\%$ & Number & $\%$ \\
\hline \multicolumn{5}{|l|}{ Unmetamorphosed } \\
\hline Plutonic & 81 & 18.7 & 61 & 16.5 \\
\hline Volcanic-hypabyssal & 9 & 2.1 & 2 & 0.5 \\
\hline Sedimentary & 2 & 0.5 & 1 & 0.3 \\
\hline Subgreenschist facies & 3 & 0.7 & 1 & 0.3 \\
\hline Greenschist facies & 23 & 5.3 & 11 & 3.0 \\
\hline Amphibolite facies & 60 & 13.8 & 51 & 13.8 \\
\hline Granulite facies & 80 & 18.4 & 77 & 20.8 \\
\hline "Gneiss" & 176 & 40.6 & 166 & 44.9 \\
\hline Total & 434 & & 370 & \\
\hline
\end{tabular}




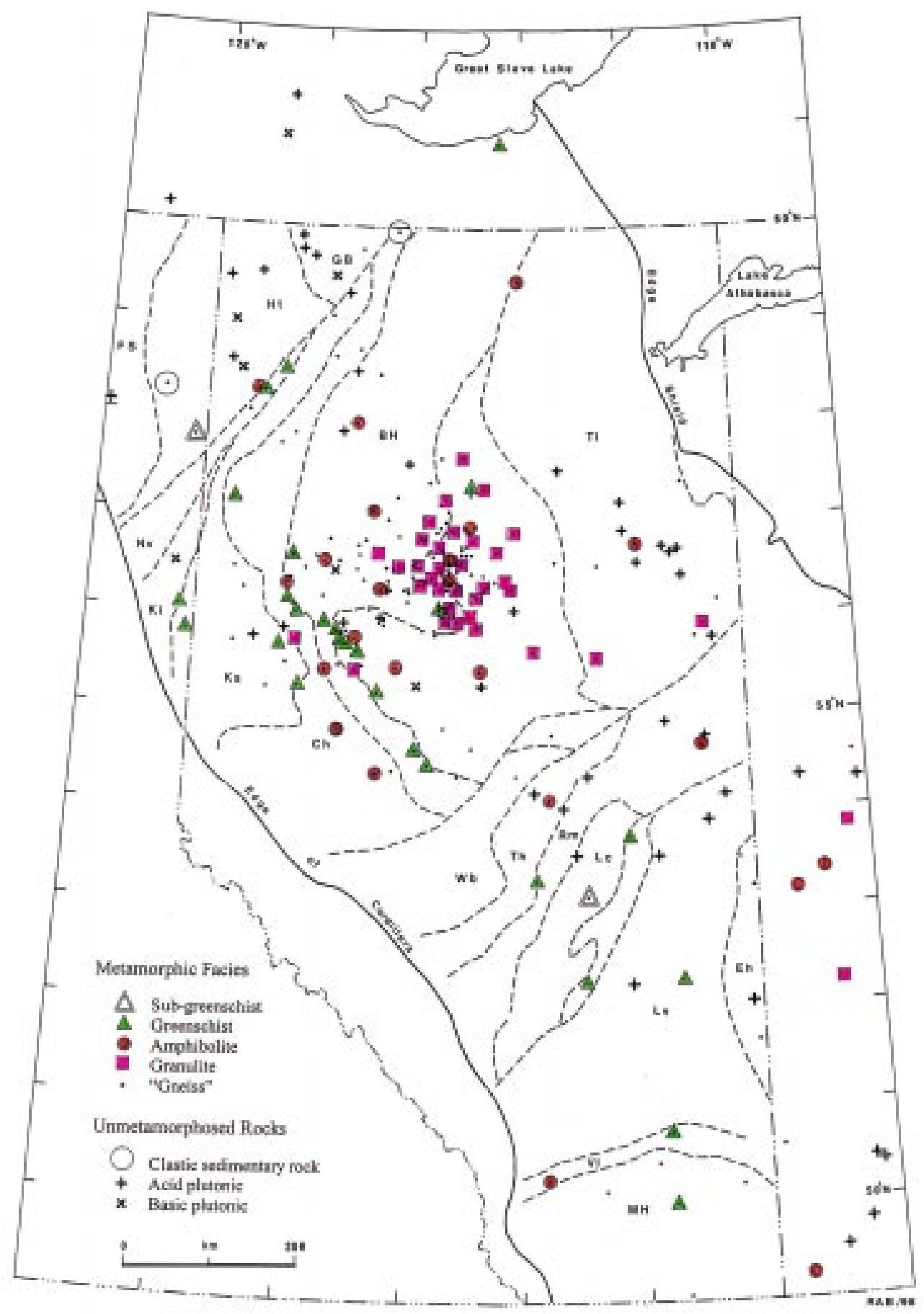

FIG. 1. Metamorphic facies of core samples from the Precambrian basement of Alberta and adjacent parts of British Columbia and Saskatchewan, as determined by petrographic study. The map of tectonic subdivisions of Ross et al. (1991) forms the background; domains are identified by the following abbreviations: FS: Ft. Simpson, Ht: Hottah, GB: Great Bear, Nv: Nova, Ki: Kiskatinaw, Ks: Ksituan, Ch: Chinchaga, BH: Buffalo Head, Tl: Taltson, Wb: Wabamun, Th: Thorsby, Rm: Rimbey, Lc: Lacombe, Lv: Loverna, Eh: Eyehill, Vl: Vulcan, MH: Medicine Hat. 


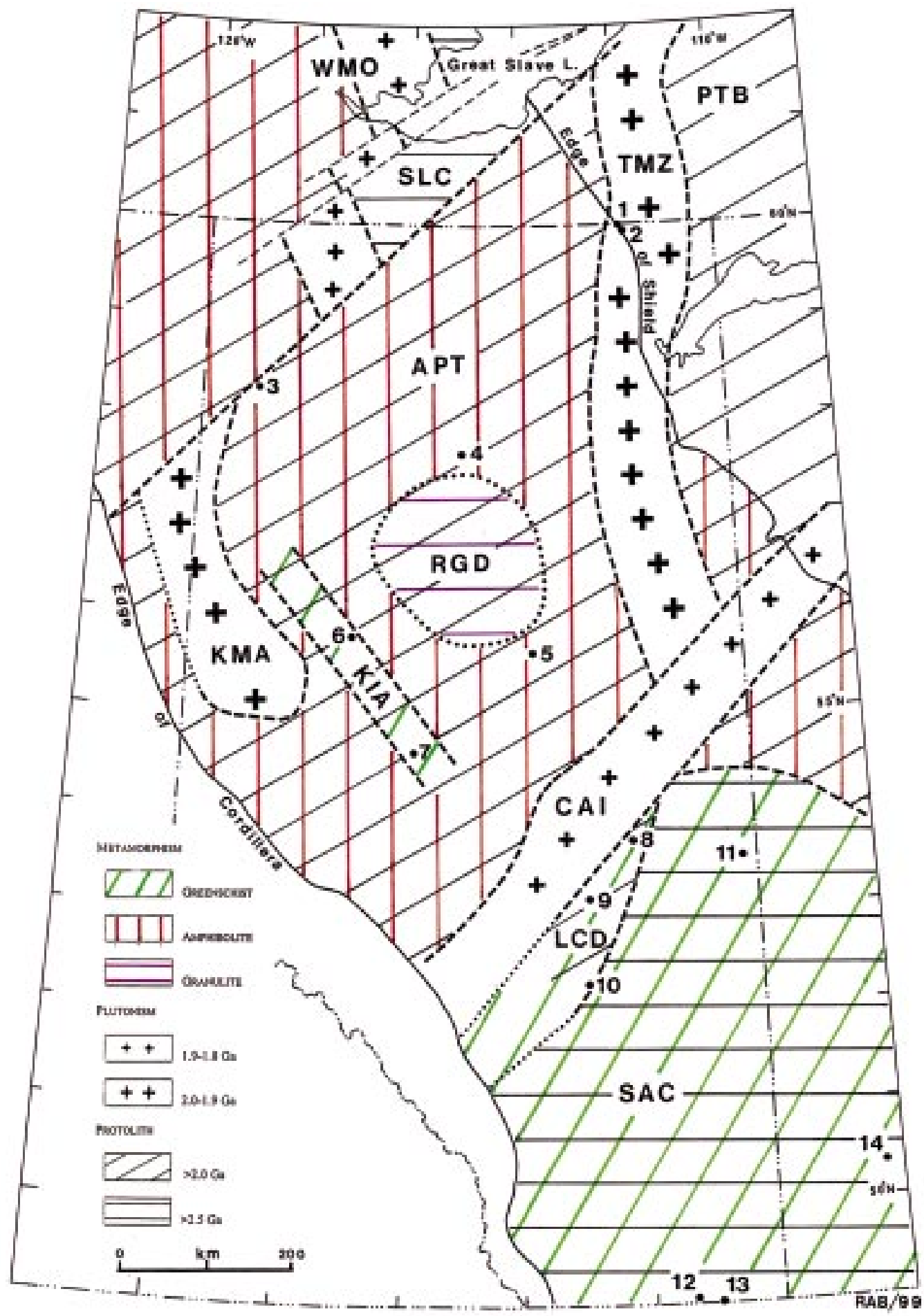

FIG. 2. Tectonometamorphic map of the Precambrian basement of Alberta. Acronyms and key localities are listed in Table 2. Geographic extent of facies domains is simplified from Figure 1. 
bining aeromagnetic trends with data on metamorphic facies and seismic discontinuities recognized on Alberta Lithoprobe Transect profiles. Some very strong lineaments used by Ross et al. (1991) correspond to petrological and geochemical boundaries suggested by Burwash \& Krupička (1970) and Burwash \& Culbert (1976). The major northeast-trending lineament across central Alberta has been shown from Alberta Lithoprobe and regional Bouguer gravity mapping to be a major thrust fault linked to the Virgin River Shear Zone in Saskatchewan (Burwash \& Muehlenbachs 1997). This single lineament on Figure 2 replaces the more complex structure shown by Ross et al. (1991). North of this major central Alberta boundary, samples of basement core showing granulite-facies assemblages are abundant and widespread. South of the boundary they are absent.

Another important boundary is the one between the Buffalo Head and Chinchaga domains, mapped originally to reflect the transition from magnetic high to low. Ross (1990) inferred this boundary to be a vertical suture-zone. Recent data from seismic surveys and oxygen isotope analyses (Burwash et al., submitted) indicate that the Chinchaga and the western margin of the Buffalo Head are part of a northwest-trending zone of crustal extension. Greenschist-facies metamorphism in this zone is spatially related to several low-angle

TABLE 2. INEERRED TECTONOMETAMORPHIC ELEMENTS, ALBERTA PRECAMBRIAN BASEMENT. WITH KEY LOCALITIES

\begin{tabular}{|c|c|c|}
\hline Symbol & Name & Facies; age \\
\hline SLC & Slave Craton & $\mathrm{A}, \mathrm{G} ;>2,5 \mathrm{Ga}$ \\
\hline WMO & Wopmay orogen & $\mathrm{P}, \mathrm{A}, \mathrm{G} ; 1.91-1.84 \mathrm{Ga}$ \\
\hline GSLSZ & Great Slave Lake shear zone & A.G; $1.98-1.73 \mathrm{Ga}$ \\
\hline PTB & Pre-Taltson basement & $P, \mathbf{R}, \mathbf{A}, \mathrm{G} ;>2,0 \mathrm{Ga}$ \\
\hline $\mathrm{TMZ}$ & Taltson magmatic zone & P; $1.99-1.91 \mathrm{Ga}$ \\
\hline APT & Athabasca polymetamorphic terrane & $P, \mathbf{R}, \mathrm{A}, \mathrm{G} ; 2.4-1.7 \mathrm{Ga}$ \\
\hline RGD & Red Earth granulite domain & $\mathrm{R}, \mathrm{A} ; 2.1-1.9 \mathrm{Ga}$ \\
\hline KIA & Kimiwan isotopic anomaly & $\mathrm{A}_{2} \mathrm{G} ; 1.93-1.7 \mathrm{Ga}$ \\
\hline $\mathrm{KMA}$ & Ksituan magmatic arc & $P ; 1.98-1.9 \mathrm{Ga}$ \\
\hline VRSZ & Virgin River shear zone & G; estimated $1.8 \mathrm{Ga}$ \\
\hline CAI & Central Alberta intrusions & $\mathrm{P} ; 1.85-1.80 \mathrm{Ga}$ \\
\hline LCD & Lacombe domain & $\mathrm{G} ; \mathrm{T}_{\mathrm{DM}} 2.4-2.3 \mathrm{Ga}$ \\
\hline SAC & Southern Alberta craton & A: $2.8-2.6 ; \mathrm{G}: 1.8 \mathrm{Ga}$ \\
\hline 1. & Pelican Rapids, Slave River & Chacko (1997) $6.8 \mathrm{kbar}$ \\
\hline 2. & Mountain Rapids, Slave River & Chacko (pers. commun.) $7.0 \mathrm{kbar}$ \\
\hline 3. & Rainbow Lake 16-18 & GSC $79,2808 \pm 10 \mathrm{Ma}$ \\
\hline 4. & Calstan Senex Creek 4-3 & $\mathrm{UA} 86194,850^{\circ} \mathrm{C}$ \\
\hline 5. & Imperial Pelican Hills 6-10 & $\mathrm{UA} 4016,850^{\circ} \mathrm{C}$ \\
\hline 6. & Imperial Kimiwan 1 & UA 2208, Ar-Ar \\
\hline 7. & Home, et al. Virginia Hills $16-12$ & UA $3186, \mathrm{Ar}-\mathrm{Ar}$ \\
\hline 8. & Imperial Willingdon 1 & RAB 50-65, G, volcanic \\
\hline 9. & Imperial Dinant & UA 2174, phyllite \\
\hline 10. & CPOG Oberlin $10-15$ & GSC $19, \mathrm{G}$, volcanic \\
\hline 11. & Husky DH Lloyd 10-15 & Plint \& Ross (1993), Ar-Ar \\
\hline 12. & Home Pacific Knappen 16-29 & $\mathrm{GSC} 4,3278 \pm 22 \mathrm{Ma}$ \\
\hline 13. & Two Nine diatreme, Tp. 2 , Rge. 9 & Davis et al. (1995) xenoliths \\
\hline 14. & British American Wilhelm 1-9 & UA 3634 , rhyolite \\
\hline
\end{tabular}

Facies: P plutonic, R granulite, A amphibolite, G greenschist. Collections: GSC (Villeneuve et al. 1993), UA (University of Alberta), RAB (Burwash 1957). Numbered localities are shown in Figure 2. faults, roughly parallel to but not coincident with the boundary chosen by Ross et al. (1991). Because of the sparseness of Precambrian core samples for southern Alberta, we also reduced the number of basement divisions. Tectonometamorphic elements identified with acronyms on Figure 2 are listed in Table 2.

\section{Ages of Metamorphism}

$\mathrm{K}$-Ar dating of the Alberta basement (Burwash et al. 1962) suggested that the last regional metamorphic event in this area, the Hudsonian Orogeny (Stockwell 1961), occurred between 1600 and 1900 million years ago. Three hornblende separates dated 2000 to $2200 \mathrm{Ma}$ were interpreted as inherited "survival values" from Archean time (Burwash et al. 1962). Sm-Nd model ages (Frost \& Burwash 1986) established the presence of Archean sialic crust in southern Alberta. U-Pb dating by Ross et al. (1991) confirmed that most of southern Alberta is underlain by Archean basement rocks.

Three distinct magmatic belts with ages of 1800 to 2000 Ma were identified in the subsurface of northern Alberta by Ross et al. (1991). The Taltson Magmatic Zone (TMZ), exposed in northeastern Alberta, dated 1910 to 1990 Ma by McDonough et al. (1995), continues southward parallel to the Alberta-Saskatchewan border. Ross et al. (1991) identified the Ksituan Magmatic Arc (KMA) along the western border of Alberta, dated 1900 to 1990 Ma. The Rimbey high, a positive aeromagnetic anomaly trending northeast across central Alberta, was interpreted as a discrete 1780 to $1850 \mathrm{Ma}$ magmatic arc, referred to here as the Central Alberta Intrusions (CAI). These plutons are younger than the Taltson or Ksituan, and essentially coeval with the age of emplacement of the Wathaman batholith in Saskatchewan. The northern boundary of CIA, shown on Figure 2, represents one of the few places in Alberta where gravity and magnetic lineaments closely coincide (Burwash \& Culbert 1976). By combining seismic and gravity data, Burwash \& Muehlenbachs (1997) interpreted this lineament to be a northwest-dipping highangle thrust, the Warburg fault. CAI granites are emplaced in the thickened crust south of the Warburg fault, which can be traced northeastward to the Virgin River shear zone on the exposed Shield (Burwash \& Muehlenbachs 1997, Fig. 6).

Northwest of the CAI, the Athabasca Polymetamorphic Terrane (APT) is bounded by the Taltson and Ksituan magmatic arcs. U-Pb zircon ages in the APT range from 1900 to $2400 \mathrm{Ma}$. Depleted mantle Nd ages for this terrane, on the other hand, are all Archean (Villeneuve et al. 1993). These data suggest that the APT represents Archean crustal material that was reworked during the Paleoproterozoic.

The Kimiwan Isotopic Anomaly (KIA) (Muehlenbachs et al. 1993) occurs along the southwestern margin of Buffalo Head Terrane as drawn by Ross et al. (1991). Along a linear zone 50 by $250 \mathrm{~km}, \delta^{18} \mathrm{O}$ values 

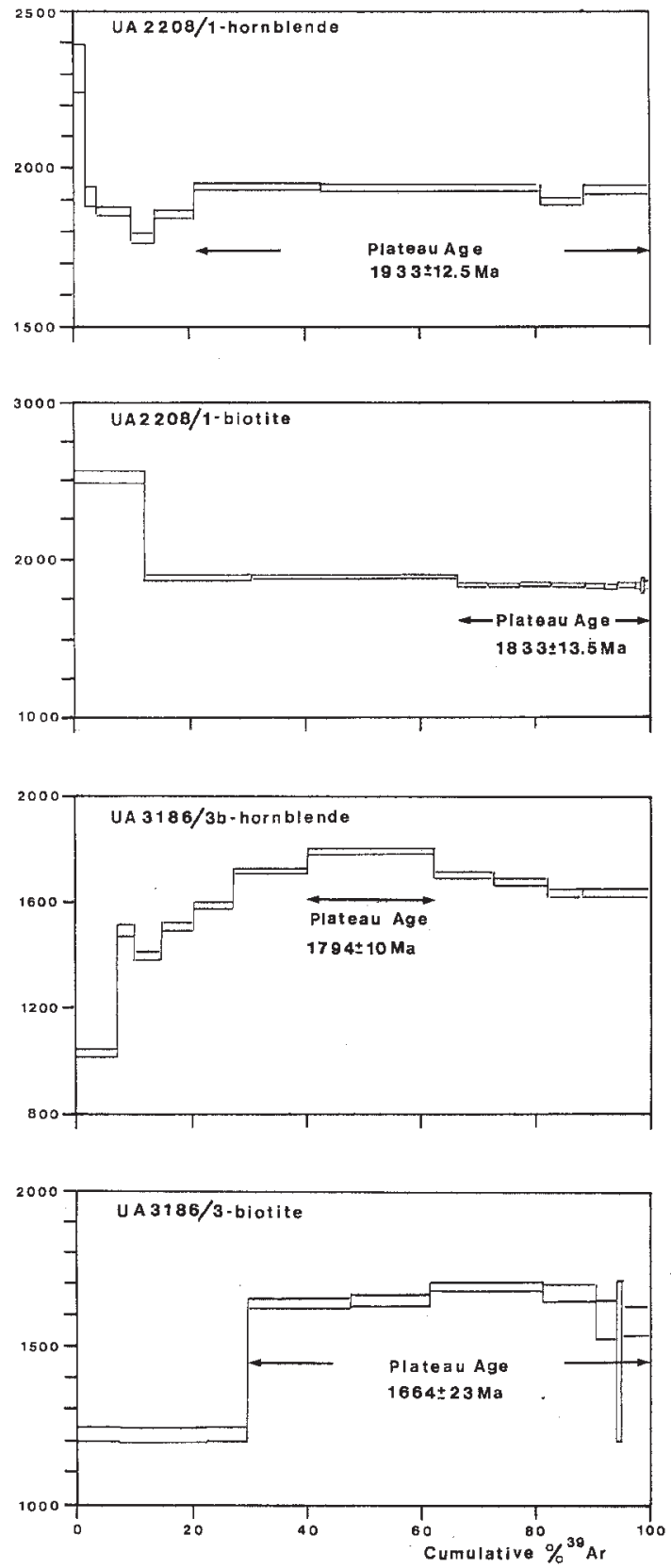

FIG. 3. ${ }^{40} \mathrm{Ar}-{ }^{39} \mathrm{Ar}$ age spectra for hornblende (magnesiohornblende) and biotite mineral separates from the amphibolite cores from the Kimiwan Isotopic Anomaly (KIA) tectonic zone. For location of samples UA2208 and UA3186, see Figure 2 and Table 2. Analyses were done by laser incremental- heating mass spectrometry at Vrije Universiteit, Amsterdam, The Netherlands. are lowered to the range 1 to 5\% (relative to Standard Mean Ocean Water). The KIA was interpreted by Burwash et al. (1995) as a zone of crustal extension formed in the late stages of the Hudsonian Orogeny. The time of the crustal extension is bracketed by $\mathrm{Rb}-\mathrm{Sr}$ and $\mathrm{K}-\mathrm{Ar}$ dates of 1780 and $1690 \mathrm{Ma}$ (Chacko et al. 1995).

In an attempt to define more rigorously the time of hydrothermal alteration and cooling of KIA, hornblende and biotite separates were prepared from each of two cores drilled in KIA. ${ }^{40} \mathrm{Ar}-{ }^{39} \mathrm{Ar}$ analysis by laser incremental-heating mass spectrometry was carried out at the Institute of Earth Sciences, Vrije Universiteit, in Amsterdam. The results are shown in Figure 3. Numerical analytical data for the ${ }^{40} \mathrm{Ar}-{ }^{39} \mathrm{Ar}$ analyses, entitled Age Calculation Program 1.4-m, are available from the Depository of Unpublished Data, CISTI, National Reseach Council, Ottawa, Ontario K1A 0S2, Canada.

Interpretation of these results is best made with reference to Figure 4. In an ${ }^{40} \mathrm{Ar}-{ }^{39} \mathrm{Ar}$ study of the Taltson Magmatic Zone, Plint \& McDonough (1995) documented a cooling history from the upper amphibolite facies (1930 Ma) to the lower greenschist facies (1800 Ma). In KIA, the biotite amphibolite from Imperial Kimiwan \#1 (UA 2208; Fig. 2, \#6) seems to have formed during regional metamorphism proximal to the Ksituan magmatic arc, almost synchronous with the Taltson arc. The $\delta^{18} \mathrm{O}$ value is low (4.38 versus $\sim 6.0 \%$ for unaltered gabbro-basalt), but petrographic study shows no chlorite and less than $1 \%$ (vol.) epidote. Because of limited hydrothermal alteration, the $\mathrm{Ar}-\mathrm{Ar}$ age obtained from hornblende, $1933 \pm 13 \mathrm{Ma}$, is similar to $\mathrm{U}-\mathrm{Pb}$ zircon ages from the nearby Ksituan magmatic arc. In contrast, hornblende from Virginia Hills 9-20 (UA 3186; Fig. 2, \#7) gives an ${ }^{40} \mathrm{Ar}-{ }^{39} \mathrm{Ar}$ age of $1794 \pm$ $12 \mathrm{Ma}$. The amphibolite from which the hornblende and biotite were separated is very fine grained, with visible veins of epidote, and with most biotite altered to chlorite. The $\delta^{18} \mathrm{O}$ value of $0.92 \%$ reflects the extensive hydrothermal alteration. The ${ }^{40} \mathrm{Ar}-{ }^{39} \mathrm{Ar}$ spectra indicate that both biotite and hornblende are "overprinted", with biotite showing an argon-loss spectrum rather than the normal excess-argon spectrum. A linear zone of crustal extension would provide the deep circulation of meteoric fluids responsible for alteration and for ${ }^{18} \mathrm{O}$ depletion. A discussion of the process of ${ }^{18} \mathrm{O}$ depletion is presented by Chacko et al. (1995). The subgreenschist to greenschist Lacombe domain borders the Central Alberta intrusive belt to the south. No valid U-Pb dates have been determined from the three wells cored in this domain.

Villeneuve et al. (1993) reported a $\mathrm{Nd}$ model age of $2.30 \mathrm{Ga}$ for the metadacite from CPOG Oberlin 10-1538-21 W4 (Fig. 2, \# 10). R.A. Creaser (pers. commun.) determined $\mathrm{T}_{\mathrm{DM}}$ values (residence time in the crust based on a depleted mantle model) for the hematite-rich phyllite from Imperial Dinant,16-17-48-20W4 (Fig. 2, \# 9; $2.36 \mathrm{Ga}$ ) and for the chloritized mica keratophyre from Imperial Willingdon 14-14-55-15 W4 (Fig.2, \#8; 


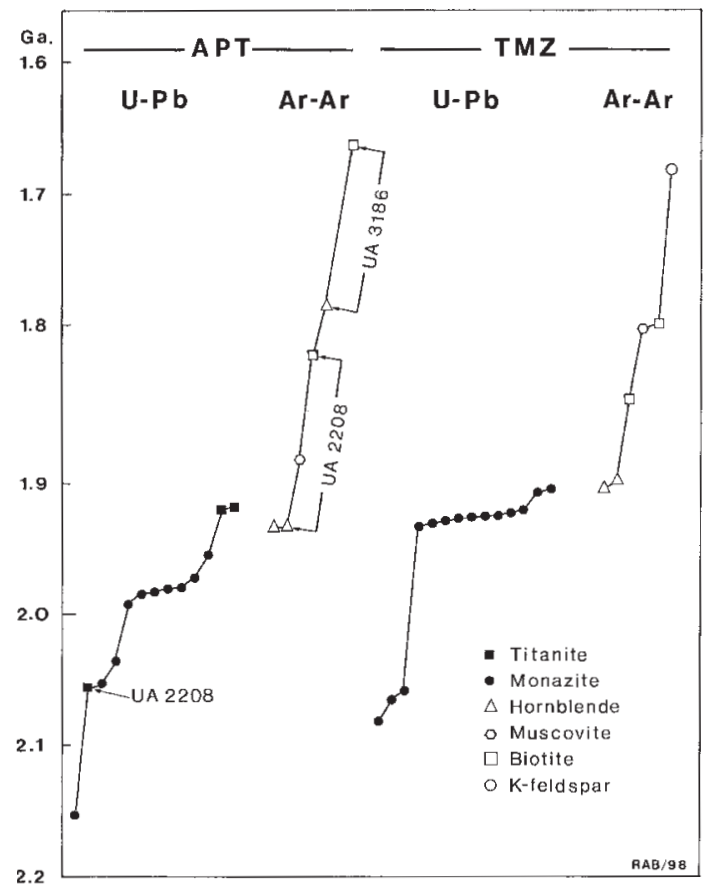

FIG. 4. Times of metamorphism in the Athabasca Polymetamorphic Terrane (APT) and Taltson Magmatic Zone (TMZ). U-Pb ages of titanite and monazite and ArAr ages of hornblende, muscovite and biotite are plotted sequentially from oldest to youngest. Plateaus on the $\mathrm{U}-\mathrm{Pb}$ curves mark times of closure following thermal peaks. ${ }^{40} \mathrm{Ar}-{ }^{39} \mathrm{Ar}$ plots from 1940 to $1800 \mathrm{Ma}$ are inferred to document the history of postorogenic cooling. Ages from UA 3186 document a later hydrothermal event. Data from: Bostock \& van Breemen (1994), Villeneuve et al. (1993), Plint \& McDonough (1995), and Table 3.

$2.41 \mathrm{Ga})$. Imperial Willingdon was drilled on the rim of a circular structure, approximately $40 \mathrm{~km}$ across, with a strong positive magnetic signature (Burwash 1957). The Willingdon structure is directly comparable to the Late Hudsonian Swift Current volcanic-epizonal plutonic center (Burwash \& Cumming 1974). The time of eruption of the volcanic rocks in the Lacombe domain is not well defined, but is probably Paleoproterozoic. The time of greenschist-facies metamorphism is inferred to be $c a$. $1.8 \mathrm{Ga}$.

Two U-Pb zircon ages greater than $2800 \mathrm{Ma}$ were reported from the Alberta basement by Ross et al. (1991). Along the Great Slave Lake shear zone across northwestern Alberta, a mylonite from Imperial Rainbow Lake (16-18-107-6W6; Fig. 2, \#3) was dated at $2808^{+30}{ }_{-27} \mathrm{Ma}$. We interpret this rock to be a tectonic slice of Slave craton from a mid-crust depth, i.e., preYellowknife basement. The only mid-Archean U-Pb zircon date, $3278^{+22}-21 \mathrm{Ma}$, comes also from a mylonitic core sample, Home Pacific Knappen (16-29-01-11W4; Fig 2, \#12). The Knappen well is located on a prominent northwest-trending aeromagnetic anomaly in the Medicine Hat block. In this instance as well, tectonic emplacement of older crust is indicated.

\section{Proterozoic Overprinting of Archean Crust}

The 1700 to $1800 \mathrm{Ma} \mathrm{K}-\mathrm{Ar}$ ages of biotite from southern Alberta (Burwash et al. 1962), when combined with the 2.7 to $3.0 \mathrm{Ga} \mathrm{Sm-Nd} \mathrm{model} \mathrm{ages} \mathrm{(Frost} \mathrm{\&}$ Burwash 1986) and 2560 to $2750 \mathrm{Ma}$ U-Pb zircon dates (Ross et al. 1991), provide a classic example of Paleoproterozoic overprinting of a dominantly Archean cratonic block. Plint \& Ross (1993) used the $1796 \pm 11$ $\mathrm{Ma} \mathrm{Ar}-\mathrm{Ar}$ age of hornblende to demonstrate the retrograde metamorphism of an orthogneiss with $\mathrm{U}-\mathrm{Pb}$ zircon age of $2601 \pm 4 \mathrm{Ma}$ (Husky DH Lloyd 10-1549-1W4; Fig. 2, \#11). The K-Ar data indicate that the southern Alberta Archean craton was heated to at least $300^{\circ} \mathrm{C}$ during the Hudsonian orogeny. The mechanism by which this relatively large Archean craton could be reheated was not apparent until Davis et al. (1995) studied xenoliths of the crust brought to the surface by Tertiary minette dykes in the Sweet Grass Hills area of southern Alberta and northern Montana. A xenolith of tonalite from the upper crust gave a $\mathrm{Pb}$ age of $2650 \mathrm{Ma}$, similar to that of drill-core samples from the southern Alberta basement. Granulite xenoliths from locality Two-Nine (Fig. 2, \#13) record temperatures of 925 to $975^{\circ} \mathrm{C}$ and pressures of 11.3 to $13.5 \mathrm{kbar}$ (Davis et al. 1995). Zircon fractions separated from these xenoliths from the lower crust gave U-Pb ages in the range 1693 \pm 5 to $1814 \mathrm{Ma}$. These dates indicate that the lower crust was reheated at the time of terminal collision in the Trans-Hudson Orogen (THO) some 300 to $700 \mathrm{~km}$ to the east. The inferred mechanism of heating is the escape of volatiles from the west-dipping subducted Manikewan oceanic crust of the THO. The rhyolitic volcanic rocks that erupted in southwestern Saskatchewan at this time (Fig. 2, \#14; Burwash et al. 1994) provide supporting evidence for a subducted plate. A map showing the spatial relationship was given by Burwash \& Muehlenbachs (1997, Fig. 6).

In northern Alberta, the tectonic and metamorphic history is quite different. The Athabasca Polymetamorphic Terrane (APT, Burwash et al. 1993) is a rhomboidal block bounded on the north by the Great Slave Lake shear zone, and on the south by the Central Alberta Intrusions (CAI). From evidence currently available, the APT is probably the southwestward extension of the pre-Taltson basement (PTB) exposed in the Shield in northeastern Alberta, northwestern Saskatchewan and adjacent Northwest Territories. In the Fort Smith - Hill Island Lake area of the Northwest Territories, Bostock \& van Breemen (1994) concluded that "east of the Taltson magmatic zone, 2.44 to $2.27 \mathrm{Ga}$ granites were emplaced into older, likely Archean crust". In the Tazin 
TABLE 3. U-Pb ANALYSIS OF TITANITE FROM SAMPLE UA 2208, WITH MODEL AGES

\begin{tabular}{|c|c|c|c|c|c|c|c|c|c|c|c|}
\hline $\begin{array}{l}\text { weight } U \\
\mu \mathrm{g} \quad \mathrm{ppm}\end{array}$ & $\begin{array}{c}\text { Th } \\
\text { ppm }\end{array}$ & $\begin{array}{c}\mathrm{Pb} \\
\mathrm{ppm}\end{array}$ & $\begin{array}{c}\mathrm{Th} / \mathrm{U} \mathrm{TCPb} \\
\mathrm{pg}\end{array}$ & $\begin{array}{l}{ }^{206} \mathrm{~Pb} / \\
{ }^{204} \mathrm{~Pb}\end{array}$ & $\begin{array}{c}{ }^{206} \mathrm{~Pb} / \\
{ }^{238} \mathrm{U}\end{array}$ & $\begin{array}{l}{ }^{207} \mathrm{~Pb} / \\
{ }^{235} \mathrm{U}\end{array}$ & $\begin{array}{l}{ }^{207} \mathrm{~Pb} / \\
{ }^{206} \mathrm{~Pb}\end{array}$ & ${ }^{238} \mathrm{~Pb} /$ & ${ }^{207} \mathrm{~Pb} /$ & $\begin{array}{l}{ }^{207} \mathrm{~Pb} / \\
{ }^{206} \mathrm{~Pb}\end{array}$ & $\begin{array}{c}\% \\
\text { Disc. }\end{array}$ \\
\hline
\end{tabular}

$\begin{array}{llllllllllllll}230 & 30.9 & 17.1 & 15.3 & 0.55 & 663 & 263 & 0.369 \pm 12 & 6.46 \pm 67 & 0.1269 \pm 90 & 2026 \mathrm{Ma} & 2041 \mathrm{Ma} & 2056 \mathrm{Ma} & 1.7\end{array}$

Lake area of northwestern Saskatchewan, granites dated at 2.18 to $2.36 \mathrm{Ga}$ intrude $2.6 \mathrm{Ga}$ granitic gneisses (Van Schmus et al. 1986). Magmatic activity in the APT, reported by Ross et al. (1991), is coeval with that of the pre-Taltson basement.

The zircon fractions separated from Alberta basement cores and illustrated by Villeneuve et al. (1993) are, with several notable exceptions, zoned and interpreted as reflecting magmatic crystallization. In an effort to distinguish between magmatic and metamorphic events, the U-Pb zircon data have been set aside, and emphasis has been placed on $\mathrm{U}-\mathrm{Pb}$ ages of monazite and titanite and $\mathrm{Ar}-\mathrm{Ar}$ ages of hornblende, muscovite and biotite. Figure 4 was plotted following the example of Bostock \& van Breemen (1994, Fig. 8). U-Pb and $\mathrm{Ar}-\mathrm{Ar}$ data are plotted separately for the APT, with similar data from the TMZ for comparison. In both areas, there is evidence for a pre-Hudsonian metamorphic event about 2060 Ma. Villeneuve et al. (1993) dated three crystals of monazite from the Imperial Pelican Hills in the Buffalo Head Terrane. The ${ }^{207} \mathrm{~Pb} /{ }^{206} \mathrm{~Pb}$ ages of these crystals (2035, 2055 and $2152 \mathrm{Ma}$ ) form most of the lower end of the APT array. Villeneuve et al. interpreted the monazite ages to be the result of partial resetting of $2.4 \mathrm{Ga}$ monazite isotopic values by granulite- or upper-amphibolite-facies metamorphism at about $2017 \mathrm{Ma}$. The $2056 \pm 5 \mathrm{Ma}{ }^{207} \mathrm{~Pb} /{ }^{206} \mathrm{~Pb}$ age determined by L. Heaman (Table 3 ) for titanite from Imperial Kimiwan (UA 2208; Fig. 2, \#6) may represent a metamorphic event coeval with that reported by Bostock \& van Breemen (1994) from the Rutledge River Basin in the TMZ. Alternatively, the date may reflect inherit- ance of an older component within a younger overgrowth. Further analyses are required to resolve this question. In the TMZ, the 1930 Ma monazite dates likely coincide with maximum temperatures of metamorphism associated with the intrusion of the Konth granite (Bostock \& van Breemen 1994, Berman \& Bostock 1997). Closure of the Ar-Ar system for hornblende in the APT occurred at the same time.

The Ar-Ar analyses of hornblende and biotite from UA 2208 are presumed to represent a postorogenic cooling history. Plint \& McDonough (1995) assigned a similar interpretation to their $\mathrm{Ar}-\mathrm{Ar}$ dates of hornblende, biotite and muscovite from the TMZ. The ages of the UA 3186 (Fig. 2, \#7) hornblende-biotite pair are inferred to date the postorogenic extensional tectonics in KIA. Figure 4 indicates that the Hudsonian metamorphic histories of APT and TMZ are very similar, though not identical. On the basis of $\mathrm{Nd}$ isotopic evidence, Thériault (1994) suggested that the Buffalo Head Terrane (and hence the APT) may represent the rifted equivalent of the pre-Taltson basement. De et al. (in press) studied the isotopic compositions of granitic rocks from the TMZ and concluded that both the early and late intrusions are of intracrustal origin, formed in a plate interior rather than a plate-margin setting. If this is so, parallel metamorphic histories of the pre-Taltson basement and the APT might be expected.

\section{The Red Earth Granulite Domain}

The discovery in 1956 of the Red Earth oil field led to drilling of numerous wells through the thin and ir-

TABLE 4. FELDSPAR-REINTEGRATION GEOTHERMOMETRY DATA, BASED ON MOLAR PROPORTIONS OF An, Ab AND Or IN K-FELDSPAR HOST AND EXSOLUTION LAMELLAE OF PLAGIOCLASE

\begin{tabular}{|c|c|c|c|c|c|c|c|c|c|c|c|c|c|c|c|c|}
\hline Grain & $\begin{array}{l}\text { An } \\
\mathrm{Kfs}\end{array}$ & $\begin{array}{l}\mathrm{Ab} \\
\mathrm{Kfs}\end{array}$ & $\begin{array}{c}\text { Or } \\
\mathrm{Kfs}\end{array}$ & $\begin{array}{l}\text { An } \\
\text { Pl }\end{array}$ & $\begin{array}{l}\mathrm{Ab} \\
\mathrm{Pl}\end{array}$ & $\begin{array}{l}\text { Or } \\
\text { Pl }\end{array}$ & $\underset{\mathrm{Kfs}}{\rho}$ & $\begin{array}{c}\rho \\
\mathrm{P} 1\end{array}$ & $\begin{array}{c}\mathrm{Kfs} \\
\text { vol.\% }\end{array}$ & $\begin{array}{c}\mathrm{Pl} \\
\text { vol. } \%\end{array}$ & $\begin{array}{c}\text { Kfs } \\
\text { wt. \% }\end{array}$ & $\begin{array}{c}\text { PI } \\
\text { wt. } \%\end{array}$ & $\begin{array}{r}\mathrm{Ca} \\
\text { reint. }\end{array}$ & $\begin{array}{l}\mathrm{Na} \\
\text { reint. }\end{array}$ & $\underset{\text { reint. }}{\mathrm{K}}$ & $\begin{array}{c}\mathrm{T} \\
{ }^{\circ} \mathrm{C}\end{array}$ \\
\hline $4061-2$ & 0.0015 & 0.1259 & 0.8726 & 0.2392 & 0.7388 & 0.0219 & 2.5679 & 2.6519 & 83.7 & 16.3 & 0.810 & 0.190 & 0.0466 & 0.2421 & 0.7114 & 850 \\
\hline $86058-2$ & 0.0014 & 0.0752 & 0.9234 & 0.245 & 0.7457 & 0.0094 & 2.5648 & 2.6540 & 82.9 & 17.1 & 0.801 & 0.199 & 0.0498 & 0.2085 & 0.7416 & 850 \\
\hline $86060-2$ & 0.00003 & 0.069 & 0.931 & 0.1803 & 0.8101 & 0.0096 & 2.5642 & 2.6447 & 86.3 & 13.7 & 0.837 & 0.163 & 0.0295 & 0.1900 & 0.7806 & 800 \\
\hline $86062-2$ & 0.0004 & 0.0622 & 0.9374 & 0.2256 & 0.07634 & 0.0109 & 2.5638 & 2.6507 & 86.4 & 13.6 & 0.836 & 0.164 & 0.0374 & 0.1774 & 0.7852 & 800 \\
\hline $194 a-3$ & 0.00098 & 0.059 & 0.94 & 0.1201 & 0.8693 & 0.0105 & 2.5637 & 2.6359 & 72 & 28 & 0.700 & 0.300 & 0.0367 & 0.3019 & 0.6614 & 850 \\
\hline
\end{tabular}




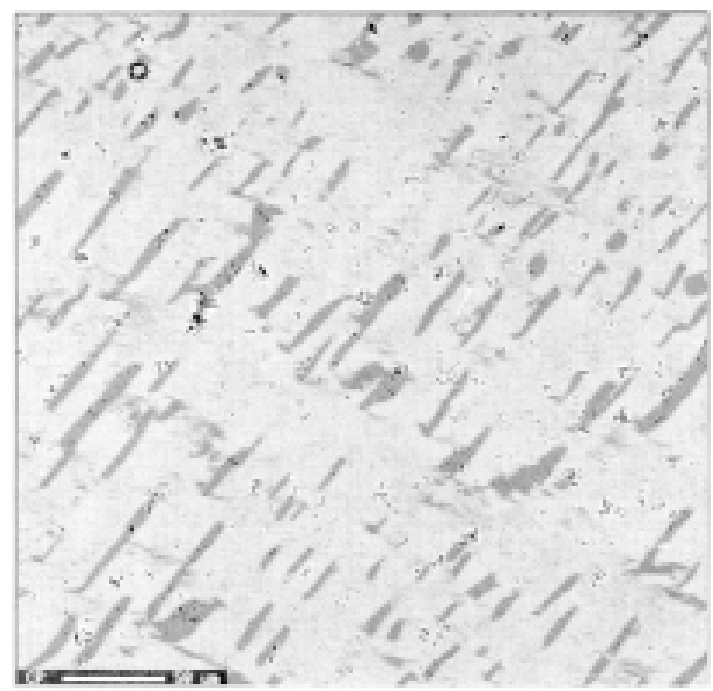

FIG. 5. Texture of perthitic feldspar from core sample UA 4016 (Fig. 2, \#5). Three plagioclase lamellae in this field of view and their adjacent host orthoclase were analyzed for feldspar-reintegration geothermometry (Table 4). regularly distributed Middle Devonian granite wash. Most of the basement cores near the Red Earth oil field show intensive dynamic metamorphism and potassium metasomatism (Burwash \& Krupička 1969). As drilling proceeded north and south of these initial wells, many basement cores were found to be gneissic and to contain the mineral assemblage orthopyroxene - biotite - quartz - plagioclase $\pm \mathrm{K}$-feldspar. In Figure 1, these samples are mapped as granulite. Orthopyroxene is commonly altered, in part or completely, to serpentinedominant pseudomorphs, whereas the biotite remains unaltered. In a study of the Trout Mountain negative gravity anomaly in the Red Earth Creek area, Burwash \& Power (1990) concluded that a granulite and retrogranulite terrane was intruded by a microcline granite pluton, 30 by $150 \mathrm{~km}$ in extent.

Preliminary estimates of temperature of 800 to $850^{\circ} \mathrm{C}$ have been obtained for the Red Earth domain using feldspar-reintegration geothermometry (Table 4). The validity of temperatures calculated using this technique is dependent on three main factors: 1) the perthite chosen must have two clearly recognizable phases with distinct boundaries (Fig. 5), 2) multiple electron-microprobe analyses of the exsolved lamellae and the host crystal must give consistent results (Table 4), and 3) an

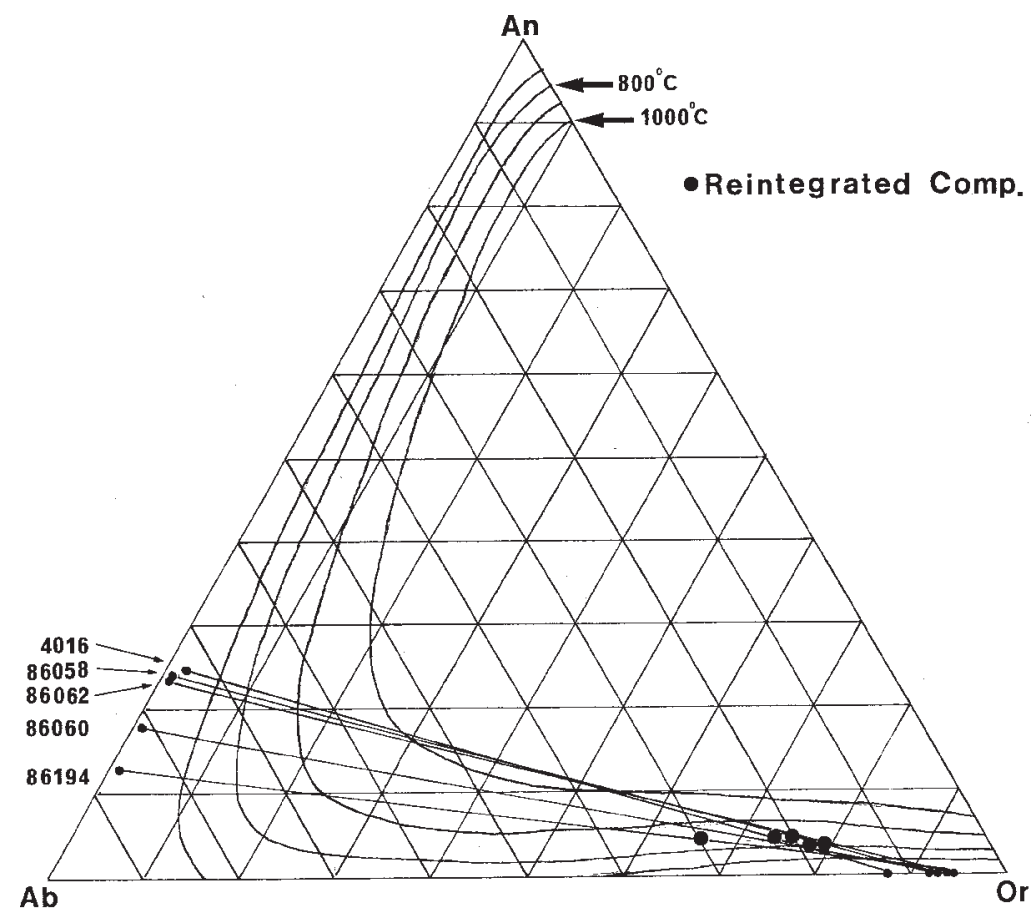

FIG. 6. Feldspar-reintegration geothermometry of perthite grains from five basement-core samples in the APT. Compositional isotherms are from the model of Fuhrman \& Lindsley (1988) for a pressure of 7 kilobars (Table 4). 


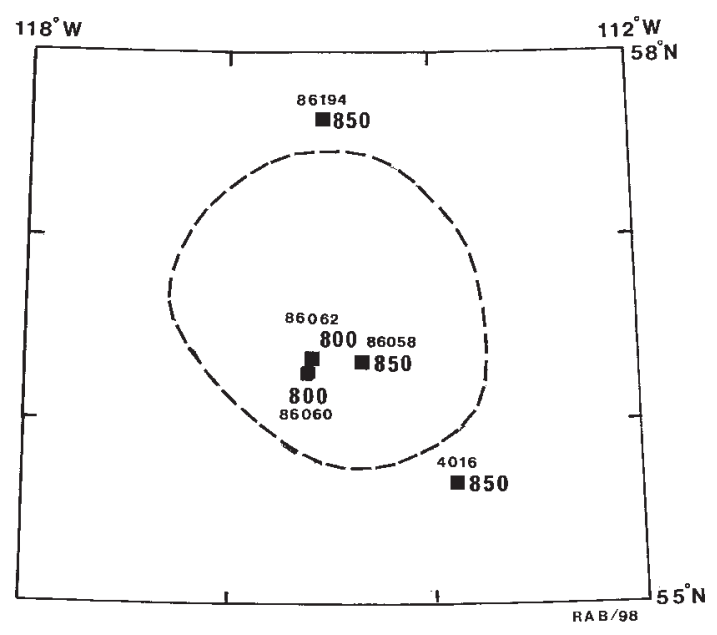

FIG. 7. Map of locations of determinations of feldspar-reintegration temperature from Figure 6. Location of petrographically determined and generalized Red Earth granulite domain from Figure 2 is outlined for comparison.

appropriate calibrated model must be used for calculation of temperatures. For this purpose, we have used the Fuhrman \& Lindsley (1988) model for a pressure of 7 kilobars (Fig. 6).

The choice of 7 kilobars was based on estimates of the pressure conditions during granulite-facies metamorphism in northeastern Alberta. For a regional suite of samples, Langenberg \& Nielsen (1982) suggested 7.5 \pm 2 kilobars. For a garnet-cordierite gneiss at Pelican Rapids, on Slave River near $60^{\circ} \mathrm{N}$ (Fig. 2, \#1), Chacko (1997) estimated 6 to 8 kilobars. A garnet-bearing granulite at Mountain Rapids (Fig. 2, \#2) has a calculated pressure of 7.0 kilobars (T. Chacko, pers. commun.).

The schematic elliptical area of granulite-facies metamorphism around Red Earth Creek (Fig. 2) was drawn to enclose the majority of the petrographically identified localities of granulite. When the feldspar-reintegration temperatures from Figure 6 are plotted in relation to this ellipse (Fig. 7), it is apparent that granulite metamorphism is more widespread than originally inferred (Fig. 2, \#4, 5). If it is possible to find perthitic textures over a sufficiently wide area of northern Alberta to permit compilation of an isotherm map of Hudsonian metamorphism, the true extent of the granulite-facies terrane may be determined.

\section{Conclusions}

The tectonic and metamorphic history of the Precambrian basement of Alberta reflects two major orogenies, the $c a$. 2.7-2.5 Ga Kenoran and the $c a .2 .0-1.7 \mathrm{Ga}$ Hudsonian (Stockwell 1961). The Kenoran Slave Cra- ton underlies a small area of northern Alberta. Most of southern Alberta is a Kenoran igneous-metamorphic terrane, possibly part of the Wyoming Craton.

Hudsonian metamorphic events are complex. Early Hudsonian (2.0-1.9 Ga) east-west compression resulted in the north-trending Taltson and Ksituan magmatic arcs. Widespread granulite-facies metamorphism occurred at about $1.9 \mathrm{Ga}$ across northern Alberta in the APT, TMZ and PTB terranes (Chacko 1997, Langenberg \& Nielsen 1982). In mid-Hudsonian time (1.9-1.8), compression shifted to northwest-southeast, resulting in the emplacement of the Central Alberta Intrusions. These are coeval with the main magmatism in the TransHudson Orogen of Saskatchewan. Late Hudsonian uplift and extensional tectonics are best documented in the Kimiwan Isotopic Anomaly in northwestern Alberta. Along a series of northwest-trending faults, the deep circulation of low- $\delta{ }^{18} \mathrm{O}$ meteoric waters resulted in greenschist-facies-altered rocks with lowered $\delta^{18} \mathrm{O}$ whole-rock values. The southern Alberta Kenoran terrane was concurrently overprinted under greenschistfacies conditions by a thermal underplating of the crust. The Athabasca Polymetamorphic Terrane has a complex Lower Proterozoic history. U-Pb dates of monazite and titanite grains suggest one period of intrusion and metamorphism, which occurred at approximately $2050 \mathrm{Ma}$, prior to reworking during the Hudsonian Orogeny.

\section{ACKNOWLEDGEMENTS}

The research on which this paper is based was supported over many years by grants from NSERC and, recently, from Lithoprobe. Access to core samples was provided by most of the major oil companies operating in western Canada. New geochronological data were provided by R.A. Creaser and L. Heaman of the University of Alberta. The calculation of feldspar-reintegration geothermometry of the APT was done with the guidance of T. Chacko. L. Shi operated the electron microprobe. R.W. Burwash transcribed the manuscript; E.J. Burwash assisted with editing. H.H. Bostock, G.M. Ross, T. Chacko, L. Heaman, and R.G. Berman helped with the review process.

\section{REFERENCES}

Berman, R.G. \& Bostock, H.H. (1997): Metamorhism in the northern Taltson Magmatic Zone, Northwest Territories. Can. Mineral. 35, 1069-1091.

Bostock, H.H. \& van Breemen, O. (1994): Ages of detrital and metamorphic zircons and monazites from a pre-Taltson magmatic zone basin at the western margin of the Rae Province. Can. J. Earth Sci. 31, 1353-1364.

Burwash, R.A. (1951): The Precambrian under the Central Plains of Alberta. M.Sc. thesis, Univ. of Alberta, Edmonton, Alberta. 
(1957): Reconnaissance of subsurface Precambrian of Alberta. Bull. Am. Assoc. Petrol. Geol. 41, 70-103.

BaAdsgaard, H. \& Peterman, Z.E. (1962): Precambrian $\mathrm{K}-\mathrm{Ar}$ dates from the Western Canada Sedimentary Basin. J. Geophys. Res. 67, 1617-1625.

Chacko, T. \& Muehlenbachs, K. (1995): Tectonic interpretation of Kimiwan Anomaly, northwestern Alberta. In Alberta Basement Transects Workshop (G.M. Ross, ed.). Lithoprobe Rep. 47, 340-349.

\& CULberT, R.R. (1976): Multivariate geochemical and mineral patterns in the Precambrian basement of western Canada. Can. J. Earth Sci. 13, 1-18.

\& Cumming, G.L. (1974): Helium source rock in southwestern Saskatchewan. Bull. Can. Petrol. Geol. 22, 405-412.

, Green, A.G., Jessop, A.M. \& Kanasewich, E.R (1993): Geophysical and petrological characteristics of the basement rocks of the Western Canada Basin. In Sedimentary Cover of the Craton in Canada (D.F. Stott \& J.D. Aitken, eds.). Geol. Surv. Can., Geology of Canada 5, 55-77.

\& KRUPIČKA, J. (1969): Cratonic reactivation in the Precambrian basement of western Canada. I. Deformation and chemistry. Can. J. Earth Sci. 6, 1381-1396.

$\&$ (1970): Cratonic reactivation in the Precambrian basement of western Canada. II. Metasomatism and isostasy. Can. J. Earth Sci. 7, 1275-1294.

, McGregor, C.R. \& Wilson, J.A. (1994): Precambrian basement beneath the Western Canada Sedimentary Basin. In Geological Atlas of the Western Canada Sedimentary Basin (G.D. Mossop \& I. Shetsen, eds.). Canadian Society of Petroleum Geologists and Alberta Geological Survey, Edmonton, Alberta (48-56).

\& Muehlenbachs, K. (1997): Tectonic setting of eastern Alberta basement granites inferred from Pearce trace element discrimination diagrams. In Alberta Basement Transects Workshop (G.M. Ross, ed.). Lithoprobe Rep. 59, 35-49.

\& Power, M.A. (1990): Trout Mountain anomaly, northern Alberta: its role in the northwest foreland of the Trans-Hudson orogen. Geol. Assoc. Can., Spec. Pap. 37, 301-311.

Chacko, T. (1997): Ultra-high temperature metamorphism at Pelican Rapids, Taltson Magmatic Zone, NE Alberta: possible implications for early Proterozoic collisional orogens. Geol. Assoc. Can. - Mineral. Assoc. Can., Program Abstr. 22, A24.

King, R., Muehlenbachs, K. \& Burwash, R.A (1995): The Kimiwan Isotopic Anomaly, a low ${ }^{18} \mathrm{O}$ zone in the Precambrian basement of Alberta: constraints on the timing of ${ }^{18} \mathrm{O}$ depletion from $\mathrm{K}-\mathrm{Ar}$ and $\mathrm{Rb}-\mathrm{Sr}$ data. In
Alberta Basement Transects Workshop (G.M. Ross, ed.). Lithoprobe Rep. 47, 335-339.

DAVIS, W.J., Berman, R. \& KJARSGAARD, B. (1995): U-Pb geochronology and isotopic studies of crustal xenoliths from the Archean Medicine Hat Block, northern Montana and southern Alberta: Paleoproterozoic reworking of Archean crust. In Alberta Basement Transects Workshop (G.M. Ross, ed.). Lithoprobe Rep. 47, 329-334.

De, S.K., Chacko, T., Creaser, R.A. \& Muehlenbachs, K. (2000): Geochemical and Nd-Pb-O isotopic systemics of granites from the Taltson Magmatic Zone, NE Alberta: implications for early Proterozoic tectonics in western Laurentia. Precamb. Res. (in press).

Frost, C.D. \& Burwash, R.A. (1986): Nd evidence for extensive Archean basement in the western Churchill Province, Canada. Can. J. Earth Sci. 23, 1433-1437.

Fuhrman, M.L. \& Lindsley, D.H. (1988): Ternary-feldspar modeling and feldspar thermometry. Am. Mineral. 73, 201-215.

Langenberg, C.W. \& Nielsen, P.A. (1982): Polyphase metamorphism in the Canadian Shield of northeastern Alberta. Alberta Research Council, Rep. 42.

McDonough, M.R., McNicholl, V.J. \& SchetselaAR, E.M. (1995): Age and kinematics of crustal shortening and escape in a two-sided oblique-slip collisional and magmatic orogen, Paleoproterozoic Taltson magmatic zone, northeastern Alberta. In Alberta Basement Transects Workshop (G.M. Ross, ed.). Lithoprobe Rep. 47, 264-308.

Muehlenbachs, K., Burwash, R.A. \& Chacko, T. (1993): A major oxygen isotope anomaly in the basement rocks of Alberta. In Alberta Basement Transects Workshop (G.M. Ross, ed.). Lithoprobe Rep. 31, 120-124.

Peterman, Z.E. (1962): Precambrian Basement of Saskatchewan and Manitoba. Ph.D. thesis, Univ. of Alberta, Edmonton, Alberta.

Plint, H.E. \& McDonough, M.R. (1995): ${ }^{40} \mathrm{Ar} /{ }^{39} \mathrm{Ar}$ and $\mathrm{K}-\mathrm{Ar}$ age constraints on shear zone evolution, southern Taltson magmatic zone, northeastern Alberta. Can. J. Earth Sci. 32, 281-291.

\& Ross, G.M. (1993): ${ }^{40} \mathrm{Ar} /{ }^{39} \mathrm{Ar}$ geochronology of selected crystalline basement samples from the Alberta Basin: the timing of Proterozoic assembly of the subsurface of western Canada. In Radiometric Age and Isotopic Studies: Report 7. Geol. Surv. Can., Pap. 93-2, 71-82.

Ross, G.M., Parrish, R.R., Villeneuve, M.E. \& Bowring, S.A. (1991): Geophysics and geochronology of the crystalline basement of the Alberta Basin, western Canada. Can. J. Earth Sci. 28, 512-522.

STOCKWELL, C.H. (1961): Structural provinces, orogenies and time classification of rocks of the Canadian Precambrian Shield. Geol. Surv. Can., Pap. 61-17, 108-118. 
Streckeisen, A.L. (1976): To each plutonic rock its proper name. Earth Sci. Rev. 12, 1-33.

ThÉRIAUlt, R.J. (1994): Nd isotopic evidence for Paleoproterozoic pre-Taltson Magmatic Zone (1.99-1.90 Ga) rifting of the western Churchill Province. In Alberta Basement Transect Workshop (G.M. Ross, ed.). Lithoprobe Rep. 37, 267-269.

Van Schmus, W.R., Person, S.S., Macdonald, R. \& SibBald, T.I.I. (1986): Preliminary results from U-Pb zircon geochronology of the Uranium City region, northwestern
Saskatchewan. In Summary of Investigations 1986. Sask. Energy \& Mines, Sask. Geol. Surv., Misc. Rep. 86-4, 108111.

Villeneuve, M.E., Ross, G.M., ThéRIault, R.J., Miles, W., PARrish, R.R. \& Broome, J. (1993): Tectonic subdivision and $\mathrm{U}-\mathrm{Pb}$ geochronology of the crystalline basement of the Alberta Basin, western Canada. Geol. Surv. Can., Bull. 447.

Received January 3, 1998, revised manuscript accepted February $15,2000$. 